\title{
Bacteremia Following Closed and Open Dental Extraction
}

\author{
Galina Gavazova $^{1}$, Eli Hristozova ${ }^{2}$, Stanimir Kisselov ${ }^{1}$, Ralitsa Raycheva ${ }^{3}$, Petia Pechalova ${ }^{1}$ \\ ${ }^{1}$ Department of Oral Surgery, Faculty of Dental Medicine, Medical University of Plovdiv, Plovdiv, Bulgaria \\ ${ }^{2}$ Department of Microbiology and Immunology, Faculty of Pharmacology, Medical University of Plovdiv, Plovdiv, Bulgaria \\ ${ }^{3}$ Department of Social Medicine and Community Health, Faculty of Public Health, Medical University of Plovdiv, Plovdiv, Bulgaria
}

Corresponding author: Petia Pechalova, Department of Oral Surgery, Faculty of Dental Medicine, Medical University of Plovdiv, 3 Christo Botev Blvd., 4000 Plovdiv, Bulgaria; E-mail: pechalova@abv.bg;

Received: 27 Feb $2019 \diamond$ Accepted: 21 May 2019 Published: 31 Dec 2019

Citation: Gavazova G, Hristozova E, Kisselov S, Raycheva R, Pechalova P. Bacteremia following closed and open dental extraction. Folia Med (Plovdiv) 2019;61(4):600-4. doi: 10.3897/folmed.61.e47949.

\begin{abstract}
Aim: To observe bacteremia following closed and open dental extraction.

Material and methods: The study included two subject groups each comprising 29 participants. Group I patients received a single closed dental extraction, and group II patients - a single open extraction. Venous blood from the cubital vein of each patient was collected in three samples - preoperatively, 30 seconds after surgery, and 15 minutes after surgery. Anaerobic and aerobic hemocultures (Bact/ ALERT, BioMerieux, Inc., Durhamn, N.C.) were used to study the bacteremia process.

Results: Preoperatively, bacteremia was confirmed in 4 patients (6.9\%) undergoing closed extraction and in 1 patient (1.7\%) undergoing open extraction. Additionally, we found statistically significant relation between bacteremia and age $(p=0.002)$. Thirty seconds after surgery bacteriemia was evident in 6 patients (10.3\%) from group I and in 3 (5.2\%) from group II. Fifteen minutes following surgery bacteremia was evident in 4 patients (6.9\%) undergoing typical extraction and in one patient (1.7\%) undergoing surgical extraction. No statistically significant relation between type of extraction and presence of bacteria in the bloodstream at 30 seconds $(p=0.285)$ and at 15 minutes ( $p=0.166)$ was found. Coagulase-negative Staphylococcus was the most frequently found microorganism ( $22.2 \%$ of aerobic and $11.1 \%$ of anaerobic hemocultures). The results show greater significance of bacteremia at 30 seconds, compared to preoperative samples for both subject groups $(p=0.03$ ).
\end{abstract}

Conclusions: Bacteremia following dental extraction is unaffected by duration of intervention, type of extraction and gender.

\section{Keywords}

bacteremia, closed extraction, coagulase negative Staphylococcus, hemocultures, open extraction

\section{INTRODUCTION}

Bacteremia is defined as presence of bacteria in the bloodstream. ${ }^{1}$ It has been found that resident oral microflora consists of about 20 different species, although as many as 200 species were isolated in some individuals. ${ }^{2}$ Every damage to the oral mucosal barrier facilitates the direct contact between the macro-organism and the highly contaminat- ed oral ecosystem, resulting in micro-organisms entering the bloodstream, which may be isolated in hemocultures. Dental extraction induces damage to the periodontium, which enables biomolecules and living bacteria to enter the circulation. ${ }^{3}$ Connection between bacterial presence in bloodstream and dental extraction procedure was proven long ago. Postextraction bacteremia is distinctively characterized by its transitory nature. Many authors explored the

Copyright by authors. This is an open access article distributed under the terms of the Creative Commons Attribution License (CC-BY 4.0), 
genesis of postextraction bacteremia. ${ }^{4}$ Fewer publications are dedicated to the incidence and etiology of bacteremia following open extraction. ${ }^{5-8}$

The aim of the present study was to investigate the bacteremia following closed and open dental extraction.

\section{MATERIALS AND METHODS}

The research included 58 patients who were divided equally in two groups by type of performed dental extraction - closed or open. Inclusion criteria were: (1) good clinical health; (2) extraction of single tooth per patient. Exclusion criteria included patients who did not provide consent; patients who require multiple extractions; patients with chronic illness who take medications; patients who were treated with antibiotics in the last 6 months; patients with any oral inflammation, tumors; patients with compromised immune system, diabetes mellitus; pregnant women; patients who received or are about to receive radiotherapy; patients with malignancies. The patients from both groups do not perform any preoperatively rinses. No periodontal debridement of the teeth was provided before the dental removal.

Dental extractions were performed with regular instruments: straight elevators, English pattern forceps and dental curettes for closed extraction, and additionally used instruments for open extraction, including rotatory burs, scalpels, needle holders, surgical suture material.

Closed dental extractions were performed in the following order: (1) local anesthesia - infiltration anesthesia or block anesthesia, depending on the tooth to be extracted; (2) syndesmotomy; (3) luxation or/and rotation of the tooth; (4) traction; (5) revision of the wound; (6) compression of the cortical plates; (7) hemostasis. Open dental extraction included: (1) local nerve block anesthesia; (2) reflection of mucosal-periosteal flap; (3) uncovering of the tooth; (4) removal of bone using surgical burrs and saline irrigation, sectioning of the tooth if necessary; (5) extraction; (6) irrigation and cleaning of the empty socket; (7) restoring the flap to its original place and applying single sutures; (8) insertion of rubber drainage.

Several aerobic and anaerobic hemocultures, incubated in an automated system, were utilized to study bacteremia (Bact/ALERT, BioMerieux, Inc., Durham, N.C.). The site of venipuncture was disinfected with ethanol followed by iodine solution. Five millilitres of venous blood for each hemoculture (aerobic and anaerobic) was collected from the cubital vein. Then another sterile needle was used to aseptically transfer the material from the syringe into the container which was immediately brought to the microbiology laboratory. Three samples of paired hemocultures for aerobic and anaerobic bacteria were acquired - one was obtained preoperatively, prior to any manipulations in the mouth; another was done 30 seconds after the extraction was completed; and another was obtained 15 minutes after completion of extraction. The hemocultures were incubat- ed in BactALERT 3D 60 (BioMerieux, Inc., Durham, N.C.) for 6 days. Positive hemocultures were transferred in solid and liquid nutrient mediums and prepared by Gram staining. Identification of the isolated strains was conducted according to the standard methods ${ }^{9}$ or automatically using Vitek 2 (BioMerieux, Inc., Durham, N.C.). Some positive hemocultures that showed no bacteria through Gram staining were automatically subcultuvated up to 6 days and were deemed false-positive if no bacterial growth was evident. Hemocultures that were not marked by the device were subjected to routine incubation and transferred to solid nutrient mediums. Evident growth marked them as false-negative, whereas true-negative hemocultures showed no growth whatsoever.

\section{RESULTS}

The mean age of the patients was 33.5 years with standard deviation of 16.72, the oldest patient was 79 and the youngest was 18 years old. The mean age of subjects in the closed extraction group was 40.7 with standard deviation of 16.72 , and for subjects in the open extraction group - 26.3 years with standard deviation of 1.65. Female patients were the majority - $41(70.7 \%)$ and males were 17 (29.3). Patients' distribution by gender and age is shown in Table $\mathbf{1}$.

Twenty nine subjects received closed extraction of one tooth, another 29 subjects had open extraction. The majority of extracted teeth were third molars - 45 (77.6\%). The distribution by type of performed extraction in both study groups is shown in Fig. 1.

Preoperatively bacteremia was found in 4 (6.9\%) patients undergoing closed extraction and in one $(1.7 \%)$ of them Staphylococcus epidermidis was isolated. One patient $(1.7 \%)$ that was treated with open extraction also had Staphylococcus epidermidis. Such findings of Staphylococcus epidermidis are deemed false positive and are accounted for by sample contamination.

Samples obtained at 30 seconds after completing the extraction were positive in $6(10.3 \%)$ patients with closed extraction and in $3(5.2 \%)$ patients with open extraction. No statistical correlation was found between the two techniques and occurrence of bacteremia at 30 seconds ( $p=0.285$ ).

The samples obtained 15 minutes showed bacteremia in $4(6.9 \%)$ subjects who had typical extraction, 1 (1.7\%) of them had Staphylococcus epidermidis. Bacteriemia was also evident in one $(1.7 \%)$ of the subjects with open extraction. Again, we failed to find any statistically significant relation between the type of extraction and presence of bacteria in the bloodstream at 15 minutes $(p=0.166)$.

The collected data on isolated bacteria is shown in Table 2. Coagulase negative Staphylococcus was the most frequently occurring bacterium - it was found in $22.2 \%$ of the anaerobic and in $11.1 \%$ of the aerobic hemocultures. Its survival in both hemocultures is explained by the fact that it is a facultative anaerobe that benefits from both respiration- and fermentation-based metabolism. The second most com- 
G. Gavazova et al

Table 1. Distribution of patients by gender and age

\begin{tabular}{|c|c|c|c|c|c|c|}
\hline \multirow{2}{*}{$\begin{array}{l}\text { Gender } \\
\text { Age groups }\end{array}$} & \multicolumn{2}{|c|}{ Females } & \multicolumn{2}{|c|}{ Males } & \multicolumn{2}{|c|}{ All } \\
\hline & Number & $\%$ & Number & $\%$ & Number & $\%$ \\
\hline $11-20$ years & 2 & 3.4 & 3 & 5.2 & 5 & 8.6 \\
\hline $21-30$ years & 22 & 37.9 & 8 & 13.8 & 30 & 51.7 \\
\hline $31-40$ years & 7 & 12.1 & 4 & 6.9 & 11 & 19.0 \\
\hline $41-50$ years & 1 & 1.7 & - & - & 1 & 1.7 \\
\hline $51-60$ years & 4 & 6.9 & 1 & 1.7 & 5 & 8.6 \\
\hline $61-70$ years & 3 & 5.2 & 1 & 1.7 & 4 & 6.9 \\
\hline $71-80$ years & 2 & 3.4 & - & - & 2 & 3.4 \\
\hline All & 41 & 70.7 & 17 & 29.3 & 58 & 100 \\
\hline
\end{tabular}

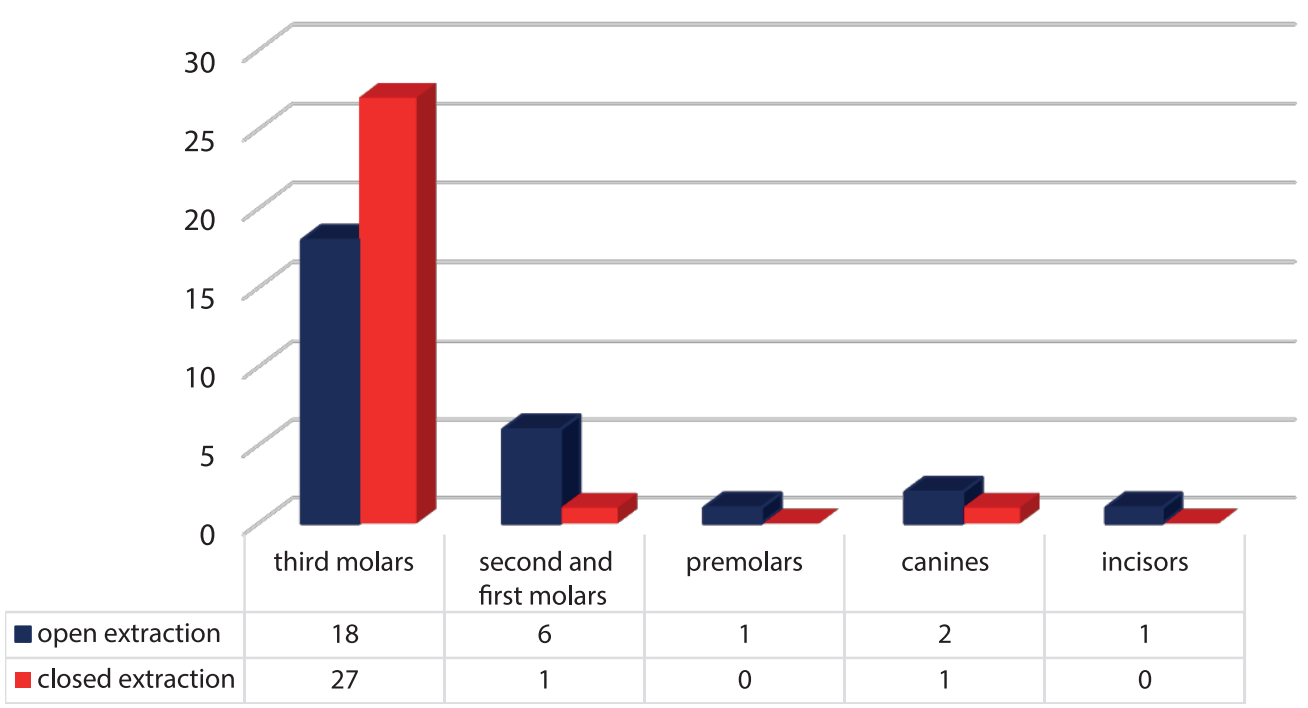

Figure 1. Distribution by type of performed extraction.

Table 2. Bacteria isolated from hemocultures

\begin{tabular}{lccc}
\hline & $\begin{array}{c}\text { Number of } \\
\text { cases with } \\
\text { bacteriemia }\end{array}$ & Isolated from aerobic hemocultures & Isolated from anaerobic hemoculture \\
\hline Preoperatively & 5 & Coagulase negative Staphylococcus & Coagulase negative Staphylococcus \\
30 seconds after extraction & 9 & Coagulase negative Staphylococcus & Streptococcus mitis/oralis \\
& & $\begin{array}{c}\text { Streptocococcus constelatus } \\
\text { Streptococcus viridans }\end{array}$ & $\begin{array}{c}\text { Streptococcus mitis / oralis } \\
\text { Streptococcus milleri }\end{array}$ \\
& 5 & Coagulase negative Staphylococcus viridans \\
15 minutes after extraction & Actinomyces viscosus & Actinomyces viscosus \\
& & & Coagulase negative Staphylococcus \\
\end{tabular}


mon bacteria were Streptococcus viridans found in $11.1 \%$ of anaerobic samples.

These results help reveal the greater significance of bacteremia at 30 seconds, compared to preoperative samples for both subject groups $(p=0.03)$.

Average duration was $16.24 \pm 2.09$ minutes for closed extraction, and $40.24 \pm 3.53$ minutes for the open extraction $(p<0.001)$. No relation between the occurrence of bacteremia and the duration of extraction was identified for both study groups ( $p=0.987$ for the 30 -second mark, $p=0.534$ for the 15-minute mark).

Interestingly, patient's age can be identified as risk factor for preoperative bacteremia ( $p=0.002$ ) but does affect bacteremia at 30 seconds $(p=0.135)$ and at 15 minutes $(p=0.088)$. Further investigation showed weak correlation between age and preoperative bacteremia (Spearman correlation coefficient $r=0.261 ; p=0.048$ ).

Our study also did not find any connection between patients' gender and preoperative $(p=0.639)$ and both postoperative samples for bacteremia $(p>0.05)$.

\section{DISCUSSION}

Conflicting data exist in the literature on bacteriemia following tooth extraction, varying from zero to $85 \% .{ }^{10}$ However, comparison with other authors' findings is problematic because of different bacteria isolation techniques utilized by them. Similar to our research were nevertheless conducted by a number of authors and their results are partially consistent with our results. Maharaj et al. ${ }^{11}$ studied the bacteremia among 108 patients who underwent dental extraction. Blood samples were collected preoperatively and at 2, 5, 15, and 30 minutes following extraction. Automatic system for analysis of hemocultures (BACTEC - Becton Dickinson, Maryland, USA) was implemented. They reported bacteremia only in one patient preoperatively (Bacillus fragilis), $32(29.6 \%)$ other patients developed transitory bacteremia after the procedure; however, no subjects had bacteremia at 15 and 30 minutes. Tomás et al. ${ }^{12}$ studied BACTEC hemocultures of 53 patients after dental extraction by obtaining blood samples preoperatively, at 30 seconds, at 15 minutes, and at 60 minutes following the procedure. Streptococcus spp. $(63.8 \%)$ was the most common finding; Streptococcus viridans was the second most common. Rajasuo et al. ${ }^{6}$ studied 16 patients who had their semi-impacted mandibular third molars surgically removed. They found 31 bacterial species, $3.9 \pm 2.6$ species per patient that were evident in the bacteremia. Most common obligate anaerobes were Prevotella, Eubacterium and Peptostreptococcus species, whereas Streptococcus viridans and Streptococcus milleri dominated the facultative anaerobic findings.

\section{CONCLUSIONS}

The greater significance of bacteremia at 30 seconds compared with preoperative samples for both subject groups $(\mathrm{p}=0.03)$ was demonstrated. The bacteremia following dental extraction is unaffected by the duration of the procedure or the mode of extraction - open or closed. No statistically significant correlation was found between the postextraction bacteriemia and patients' gender. Age also has no influence on postextraction bacteremia; however, it is a significant factor for preoperative bacteremia.

\section{ACKNOWLEDGEMENTS}

This study received funding via Project No HO-09/ 2018 from Medical University of Plovdiv.

\section{REFERENCES}

1. Benítez-Páez A, Álvarez M, Belda-Ferre P, et al. Detection of transient bacteraemia following dental extractions by $16 \mathrm{~S}$ rDNA pyrosequencing: a pilot study. PLoS One 2013; 8(3): e57782.

2. Poveda Roda R, Jiménez Y, Carbonell E, et al. Bacteremia originating in the oral cavity. A review. Med Oral Patol Oral Cir Bucal 2008; 13(6): E355-62.

3. Tomás-Carmona I, Álvarez-Fernández M. Pathogenesis of endocarditis: bacteraemia of oral origin. In: Breijo-Marquez FR, editor. Endocarditis. Croatia: InTech; 2012; 19-50.

4. Tomas I, Alvarez M, Limeres J, et al. Prevalence, duration and etiology of bacteraemia following dental extractions. Oral Dis 2007; 13: 56-62.

5. Goker K, Guvener O. Antibacterial effects of ofloxacin, clindamycin and sultamicillin on oral surgical removal of impacted third molars. J Marmara Univ Dent Fac 1992; 1: 237-49.

6. Rajasuo A, Perkki K, Nyfors S, et al. Bacteremia following surgical dental extraction with an emphasis on anaerobic strains. J Dent Res 2004; 83: 170-4.

7. Rajasuo A, Nyfors S, Kanervo A, et al. Bacteremia after plate removal and tooth extraction. Int J Oral Maxillofac Surg 2004; 33: $356-60$.

8. Tomas I, Pereira F, Llucian R, et al. Prevalence of bacteraemia following third molar surgery. Oral Dis 2008; 14: 89-94.

9. Murray PR, Baron EJ, Pfaller MA, et al (editors). Manual of clinical microbiology, 6th ed. 1995 ASM Press, Washington, D.C.

10. Guntheroth WG. How important are dental procedures as a cause of infective endocarditis? Am J Cardiol 1984; 54: 797-801.

11. Maharaj B, Coovadia Y, Vayej AC. An investigation of the frequency of bacteraemia following dental extraction, tooth brushing and chewing. Cardiovasc J Afr 2012; 23(6): 340-4.

12. Tomás I, Alvarez M, Limeres J, et al. Prevalence, duration and aetiology of bacteraemia following dental extractions. Oral Dis 2007 ; 13(1): 56-62. 


\title{
Бактериемия после закрытого и открытого удаления зубов
}

\author{
Галина Гавазова ${ }^{1}$, Ели Христозова ${ }^{2}$, Станимир Киселов $^{1}$, Ралица Райчева ${ }^{3}$, Петя Печалова ${ }^{1}$ \\ ${ }^{1}$ Кафедра „Оральная хирургия", Факультет дентальной медицинь, Медицинский унивреситет - Пловдив, Пловдив, Болгария. \\ ${ }^{2}$ Кафедра микробиологии и иммунологии, Факультет фармаџии, Медицинский университет - Пловдив, Пловдив, Болгария \\ ${ }^{3}$ Кафедра соииальной медицины и общественного здравоохранения, Факультет общественного здравоохранения, Медицинский университет - \\ Пловдив, Пловдив, Болгария
}

Адрес для корреспонденции: Петя Печалова, Кафедра „Оральная хирургия”, Факультет дентальной медицины, Медицинский университет - Пловдив, бул. „Христо Ботев” № 3, 4000 Пловдив, Болгария; E-mail: pechalova@abv.bg; Тел.:

Дата получения: 27 февраля 2019 Дата приемки: 21 мая 2019 Дата публикации: 31 декабря 2019

Образец цитирования: Gavazova G, Hristozova E, Kisselov S, Raycheva R, Pechalova P. Bacteremia following closed and open dental extraction. Folia Med (Plovdiv) 2019:61(4):600-4. doi: 10.3897/folmed.61.e47949.

\section{Абстракт}

Цель: Проследить бактериемию после закрытого и открытого удаления зубов.

Материалы и методы: В исследование были включены 2 группы пациентов, каждая из которых состояла из 29 участников. Пациенты группы 1 перенесли одно закрытое удаление зубов, а пациенты группы 2 перенесли одно открытое удаление. Венозную кровь брали из локтевой вены каждого пациента в трёх образцах - до операции, через 30 секунд после операции и через 15 минут после операции. Аэробные и анаэробные гемокультуры (Bact / ALERT, BioMerieux, Inc., Durhamn, N.C.) были использованы для изучения процесса бактериемии.

Результаты: В предоперационный период бактериемия была выявлена у 4 пациентов (6,9\%), которым была проведена закрытая экстракция, и у одного пациента (1,7\%), которому была проведена открытая экстракция. Кроме того, мы обнаружили статистически значимую связь между бактериемией и возрастом пациента ( $\mathrm{p}=0,002)$. Через тридцать секунд после операции бактериемия наблюдалась у 6 пациентов (10,3\%) в I группе и у 3 (5,2\%) во II группе. Через пятнадцать минут после операции бактериемия наблюдалась у 4 пациентов (6,9\%), которым было выполнено плановое удаление, и у 1 пациента (1,7\%) - после хирургического удаления. Не было обнаружено статистически значимой разницы между типом экстракции и наличием бактерий в кровотоке через 30 секунд после операции $(\mathrm{p}=0,285)$ и через 15 минут после операции $(\mathrm{p}=0,166)$. Коагулазонегативный стафилококк был наиболее часто идентифицированным микроорганизмом $(22,2 \%$ аэробных и $11,1 \%$ анаэробных гемокультур). Результаты показывают большую значимость бактериемии через 30 с. по сравнению с предоперационными образцами для обеих групп ( $\mathrm{p}=0,03)$.

Выводы: Бактерии после удаления зубов не зависят от продолжительности вмешательства, типа удаления и пола.

\section{Ключевые слова}

бактериемия, открытая экстракция, закрытая экстракция, гемокультуры, коагулазонегативный стафилококк 